\title{
Influence of Priming on Growth, Yield and Seed Quality Parameters in Chickpea (Cicer arietinum L.)
}

\author{
S. Chaitra*, A.K. Chaurasia and Bineeta M. Bara
}

Naini Agricultural Institute, Sam Higginbottom University of Agriculture, Technology and Sciences. Prayagraj-211007, India

*Corresponding author

\section{A B S T R A C T}

Keywords

Chickpea, biopriming, $T$.

viride, $P$. fluroscence,

Neem leaf extract, Tulasi

leaf extract, Coconut

water, Azospirillum

Article Info

Accepted:

15 July 2019

Available Online:

10 August 2019
The present study was done to know the efficiency of biopriming on growth, yield and seed quality in chickpea. The experimental factors were laid out in RBD with three replications. Chickpea seeds were bioprimed with 13 treatments combinations (Trichoderma viride@10gm/ $\mathrm{kg}$, Pseudomonas fluroscence@10gm/kg, Neem leaf extract@10ml/kg, Tulasi leaf extract@10ml/kg, Coconut water@10ml/kg, Azospirillum@10ml/kg). Among the above treatments tested, the treatment combination of Trichoderma viride + Pseudomonas fluroscence@ $10 \mathrm{ml} / \mathrm{kg}$ shows the highest plant height (40.9), Number of primary branches (6.4), Seed yield per plant (19.45), Seed yield per plot (1284.36).

\section{Introduction}

Chickpea (Cicer arietinum $\mathrm{L}$.) $2 \mathrm{n}=16$, belongs to family leguminaceae. It is also known as Bengal gram. Gram is the most important rabi pulse crop grown in India. Rank first in area as well as in production of gram (FAO, 2012). In world it is grown in an area of about 12.75 million hectares with an annual production of 8.76 million tonnes and average yield of 687 $\mathrm{kg} / \mathrm{ha}$. In India it is grown on an area about 8.26 million hectares with an annual production of 6.2 million tonnes and average yield of $751 \mathrm{~kg} / \mathrm{ha}$. Madhya Pradesh is the largest producer of chickpea, which covers 2.63 million hectares area with the total annual production of 2.40 million tonnes with an average production of $913 \mathrm{~kg} / \mathrm{ha}$ (Agriculture Ministry of India, NB Research, 2009).

Chickpea contributes $45-47 \%$ of the total pulse production and about $40 \%$ of total pulse growing area in the country. The average yield of chickpea is very low because it is mostly grown as rain fed crop with or without application of balance fertilizer. 
The rained being generally separative, result in low production. Suitable status of moisture in the soil and balance fertilizer has a profound influence in the yielding capacity of chickpea. Chickpea is largely grown under residual moisture conditions.

Proper germination and better establishment of the plant for normal plant population is a major cause responsible for low yield of chickpea.

\section{Materials and Methods}

The Research study was conducted at experimental research field, Department of Genetics and Plant Breeding, Naini Agriculture Institute, Sam Higginbottam University of Agriculture, Technology and Sciences, Prayagraj during Rabi-2018.

The experiment was conducted in Randomized Block Design (RBD) with three replications. [ $\mathrm{T}_{0}:$ Control, $\mathrm{T}_{1}:$ Trichoderma viride@ $10 \mathrm{gm} / \mathrm{kg}, \quad \mathrm{T}_{2}$ :Pseudomonas fluroscence@10gm $/ \mathrm{kg}, \quad \mathrm{T}_{3}:$ Neem leaf extract@10ml/kg, T4:Trichoderma viride + Pseudomonas_fluroscence@10ml/kg, $\mathrm{T}_{5}$ :Tulasi leaf extract@10ml/kg, $\mathrm{T}_{6}$ :Pseudomonas fluroscence + Coconut water@10ml/kg, T7:Coconut water@10ml/kg, $\mathrm{T}_{8}$ :Trichoderma viride + Coconut water@10ml/kg, T9:Azospirillum@10gm/kg, $\mathrm{T}_{10}$ :Coconut water + Tulasi leaf extract@10ml $/ \mathrm{kg}, \quad \mathrm{T}_{11}$ : Azospirillum + Coconut water@10ml/kg, $\mathrm{T}_{12}$ :Tulasi leaf extract + Neem leaf extract@10ml/kg].

\section{Results and Discussion}

In plant growth parameters (plant height $(\mathrm{cm})$ and number of primary branches) of chickpea crop the treatment T4 (Trichoderma viride + Pseudomonas fluorescence @ $10 \mathrm{gm} / \mathrm{kg}$ ) shown maximum performance in all plant growth parameters and it was followed by $\mathrm{T} 1$
(Trichodermaviride@10gms $/ \mathrm{kg}$ ) and the least performance was given by T0 (control) while compared with the other treatment combinations.

The minimum days to $50 \%$ flowering (56 days) was recorded in treatment $\mathrm{T}_{4}$ (Trichoderma viride + Psedumonas fluorescence@10 gm $/ \mathrm{kg}$ seed) and it was followed by treatment $\mathrm{T}_{1}$ (Trichoderma viride @ $10 \mathrm{gm} / \mathrm{kg}$ seed). The maximum days to $50 \%$ flowering (69.8 days) was recorded in the treatment combination $\mathrm{T}_{0}$ (control).

In yield parameters (number of pods per plant, seed yield per plant (g) and seed yield per plot (g)) of chickpea crop the treatment combination $\mathrm{T}_{4}$ (Trichoderma viride + Pseudomonas fluorescence @ $10 \mathrm{gm} / \mathrm{kg}$ ) shown maximum performance in all the yield parameters and it was followed by $T_{1}$ (Trichodermaviride@10gms/kg) and the least performance was given by $\mathrm{T}_{0}$ (control) while compared with the other treatment combinations

In seed quality parameters (germination (\%), root length, shoot length, seedling length, seedling dry weight, vigour index-I and vigour index-II) of chickpea crop the treatment combination $\mathrm{T}_{4}$ (Trichoderma viride + Pseudomonas fluorescence @10gm/kg) shown maximum performance in all the yield parameters and it was followed by $T_{1}$ (Trichodermaviride@10gms $/ \mathrm{kg}$ ) and the least performance was given by $\mathrm{T}_{0}$ (control) while compared with the other treatment combinations

Based on experiment conducted the treatment combination $\mathrm{T}_{4}$ [Trichoderma viride + Pseudomonas fluroscence@10gms / kg seed combination] is recommended as the best treatment combination for obtaining the better growth, yield and quality seed in chickpea crop (Table 1 and 2). 
Table.1 Mean performance of growth and yield parameters in chickpea during kharif-2018

\begin{tabular}{|c|c|c|c|c|c|c|c|}
\hline Treatments & $\begin{array}{l}\text { Plant height } \\
\text { (cm) }\end{array}$ & $\begin{array}{c}\text { No. of } \\
\text { primary } \\
\text { branches }\end{array}$ & $\begin{array}{c}\text { Days to } 50 \% \\
\text { flowering }\end{array}$ & $\begin{array}{l}\text { Days to } \\
\text { maturity }\end{array}$ & $\begin{array}{c}\text { No. of pods } \\
\text { per plant }\end{array}$ & $\begin{array}{c}\text { Seed yield } \\
\text { per plant }(\mathrm{g})\end{array}$ & $\begin{array}{c}\text { Seed yield } \\
\text { per plot }(\mathrm{g})\end{array}$ \\
\hline T0 & 31.6 & 4.2 & 69.8 & 118.6 & 53.5 & 8.46 & 540.77 \\
\hline T1 & 38.1 & 6.2 & 58.3 & 111.3 & 62.6 & 17.36 & 1101.07 \\
\hline $\mathbf{T} 2$ & 37.5 & 6.0 & 59.2 & 110.2 & 61.1 & 16.65 & 1075.31 \\
\hline T3 & 34.6 & 5.3 & 65.5 & 113.8 & 57.7 & 9.367 & 599.61 \\
\hline T4 & 40.9 & 6.4 & 56 & 109.06 & 64 & 19.45 & 1284.36 \\
\hline T5 & 33.3 & 5.2 & 63.9 & 115.1 & 57 & 12.26 & 793.35 \\
\hline T6 & 33.2 & 4.8 & 64 & 114.8 & 58.2 & 12.63 & 820.99 \\
\hline T7 & 35 & 4.4 & 69.8 & 116.13 & 55.13 & 9.38 & 601.84 \\
\hline T8 & 35.8 & 5.13 & 67.26 & 115.5 & 58.06 & 11.01 & 689.41 \\
\hline T9 & 36.6 & 4.5 & 63.4 & 115.9 & 59.2 & 12.72 & 806.37 \\
\hline T10 & 34.28 & 5.2 & 65.2 & 112 & 56.6 & 9.54 & 592.1 \\
\hline T11 & 33.45 & 5.5 & 66.4 & 115 & 59 & 8.86 & 564.13 \\
\hline T12 & 35.07 & 4.8 & 65.2 & 116.2 & 57.5 & 9.87 & 635.21 \\
\hline Mean & 35.37 & 5.24 & 64.16 & 114.14 & 58.46 & 12.124 & 777.27 \\
\hline CD at $5 \%$ & 0.758 & 0.675 & 3.74 & 3.97 & 2.85 & 1.32 & 88.47 \\
\hline SE. $\mathbf{m}$ & 0.259 & 0.232 & 1.283 & 1.36 & 0.98 & 0.454 & 30.37 \\
\hline SE. d & 0.368 & 0.329 & 1.82 & 1.924 & 1.39 & 0.642 & 42.95 \\
\hline
\end{tabular}


Table.2 Mean performance of seed quality parameters in chickpea during kharif-2018

\begin{tabular}{|c|c|c|c|c|c|c|c|c|}
\hline Treatments & Germination \% & $\begin{array}{l}\text { Root length } \\
\text { (cm) }\end{array}$ & $\begin{array}{c}\text { Shoot } \\
\text { length }(\mathrm{cm})\end{array}$ & $\begin{array}{c}\text { Seedling } \\
\text { length }(\mathrm{cm})\end{array}$ & $\begin{array}{l}\text { Seedling dry } \\
\text { weight (mg) }\end{array}$ & $\begin{array}{l}\text { vigour } \\
\text { index-I }\end{array}$ & $\begin{array}{c}\text { vigour } \\
\text { index-II }\end{array}$ & Seed index \\
\hline T0 & 84.25 & 12.9 & 8.6 & 21.60 & 11.35 & 1816.62 & 956.7 & 10.22 \\
\hline T1 & 90.75 & 18.62 & 12.8 & 31.43 & 19.55 & 2850.48 & 1773.2 & 15.64 \\
\hline $\mathbf{T 2}$ & 88.5 & 18.74 & 12.7 & 31.47 & 17.05 & 2784.37 & 1507.07 & 14.81 \\
\hline T3 & 86.5 & 16.28 & 10.4 & 26.71 & 15.7 & 2307.13 & 1360.92 & 12.78 \\
\hline T4 & 94 & 19.75 & 14.13 & 33.89 & 20.8 & 3185.25 & 1954.95 & 16.17 \\
\hline T5 & 88.25 & 16.12 & 10.03 & 26.16 & 14.05 & 2307.89 & 1239.47 & 14.45 \\
\hline T6 & 86.5 & 17.04 & 9.57 & 26.63 & 15.32 & 2305.77 & 1325.37 & 13.98 \\
\hline $\mathbf{T 7}$ & 87.5 & 13.68 & 9.29 & 22.98 & 12.45 & 2011.48 & 1087.8 & 10.8 \\
\hline T8 & 82 & 14.3 & 10.17 & 24.53 & 12.67 & 2009.97 & 1027.87 & 12.98 \\
\hline T9 & 84.35 & 15.81 & 9.54 & 25.35 & 14.32 & 2136.24 & 1207.12 & 14.17 \\
\hline T10 & 86 & 16.24 & 9.29 & 25.54 & 16.47 & 2197.44 & 1418.97 & 12.49 \\
\hline T11 & 87 & 15.15 & 10.71 & 25.88 & 17 & 2251.36 & 1480.6 & 12.92 \\
\hline T12 & 84.5 & 15.11 & 10.61 & 25.74 & 13.8 & 2175.42 & 1172.42 & 13.94 \\
\hline Mean & 86.923 & 16.1480 & 10.611 & 26.76 & 15.426 & 2333.80 & 1347.115 & 13.491 \\
\hline CD & 6.05 & 2.06 & 2.34 & 3.29 & 2.67 & 320.109 & 239.163 & 2.67 \\
\hline SE.m & 2.12 & 0.72 & 0.82 & 1.15 & 0.93 & 111.906 & 83.608 & 0.94 \\
\hline SE.d & 2.98 & 1.02 & 1.16 & 1.63 & 1.32 & 158.259 & 118.240 & 1.32 \\
\hline
\end{tabular}




\section{References}

Bapurayagouda BP (2010). Effect of fungicidal seed treatment on control of grain smut incidence, seed yield and quality and storability of rabi sorghum [Sorghum bicolor (L.) Moench.], M. Sc. (Agri.) Thesis, Univ. Agric. Sci., Dharwad, Karnataka (India).

Butler LH, Hay FR, Ellis RH, Smith RD, Murray TB (2009). Priming and redrying improve the survival of mature seeds of Digitalis purpurea during storage, Ann. Botany 103:1261-1270

Ehsanfar S, Modarres-Sanavyand SA, Tavakkol- Afshari R (2006). Effects of osmo priming on seed germination of canola (Brassica napus L.) under salinity stress, Commun. Agricultural Applied Biology Science. 71: 155-159.

Gholami Shahsavani S, Nezarat S (2009). The Effect of Plant Growth Promoting Rhizobacteria (PGPR) on Germination, Seedling Growth and Yield of Maize, World Academy of Science, Engineering and Technology.; 49:1924.

Harris D, Joshi A, Khan PA, Gothakar P, Sodhi PS. Onfarm (1999) seed priming in semi-arid agriculture: Development and evaluation in corn, rice and chickpea in India using participatory methods. Exeperimental Agriculture. 35: $15-29$

Iqbal M, Ashraf M, Jamil A, Rehmaan S (2006). Does seed priming induce changes in the level of some endogenous plant hormones in hexaploid wheat plant under salt stress. International journal of Planl Biology, 48181-89.

Khan HA, Ayub CM, Pervez MA, Bilal RM, Shahid MA Ziaf K (2009). Effect of seed priming with $\mathrm{NaCl}$ on salinity tolerance of hot pepper (Capsicum annuum L.) at seedling stage. Soil Environment. 28: 81-87.

Sivritepe HO, Dourado AM (1955). The effect of priming treatments on the viability and accumulation of chromosomal damage in aged pea seeds, Ann. Botany. 75: 165-171.

Soeda Y, Konings MCJM, Vorst O, van Houwelingen AMML, Stoopen GM, Maliepaard CA (2005). Gene expression programs during Brassica oleracea seed maturation, osmopriming, and germination are indicators of progression of the germination process and the stress tolerance level, Plant Physiology. 137: 354-368.

\section{How to cite this article:}

Chaitra, S., A.K. Chaurasia and Bineeta M. Bara. 2019. Influence of Priming on Growth, Yield and Seed Quality Parameters in Chickpea (Cicer arietinum L.). Int.J.Curr.Microbiol.App.Sci. 8(08): 1915-1919. doi: https://doi.org/10.20546/ijcmas.2019.808.225 